\title{
GAP-43 in synaptic plasticity: molecular perspectives
}

This article was published in the following Dove Press journal:

Research and Reports in Biochemistry

18 June 2015

Number of times this article has been viewed

\section{Matthew R Holahan \\ Department of Neuroscience, Carleton University, Ottawa, ON, Canada}

Correspondence: Matthew R Holahan Department of Neuroscience, Carleton University, I I 25 Colonel By Drive, 325 Life Sciences Research Building, Ottawa, ON, Canada KIS 5B6

Email matthewholahan@carleton.ca
Abstract: The growth-associated protein, GAP-43 (also known as F1, neuromodulin, B-50), participates in the developmental regulation of axonal growth and neural network formation via protein kinase C-mediated regulation of cytoskeletal elements. Transgenic overexpression of GAP-43 can result in the formation of new synapses, neurite outgrowth, and synaptogenesis after injury. In a number of adult mammalian species, GAP-43 has been implicated in the regulation of synaptic transmission and plasticity, such as long-term potentiation, drug sensitization, and changes in memory processes. This review examines the molecular and biochemical attributes of GAP-43, its distribution in the central nervous system, subcellular localization, role in neurite outgrowth and development, and functions related to plasticity, such as those occurring during long-term potentiation, memory formation, and drug sensitization.

Keywords: GAP-43, protein kinase C, axons, development, regeneration, long-term potentiation, memory

\section{Molecular and biochemical characteristics}

The growth-associated protein (GAP-43) is associated with presynaptic neuronal outgrowth and neuronal plasticity in general (Figure 1). ${ }^{1}$ The GAP-43 gene includes three exons. ${ }^{2}$ The first exon encodes the membrane targeting domain, the second exon encodes a calmodulin-binding domain and a protein kinase $\mathrm{C}$ (PKC) phosphorylation site, while the $5^{\prime}$-flanking sequence directs initiation of RNA transcription from several sites. $^{2}$ Among the various tissue types and cell types that have been examined, GAP-43 mRNA is expressed only in neurons (Figure 2A). ${ }^{3}$ Once transcribed, GAP-43 mRNA is stabilized by $\mathrm{HuD},{ }^{4}$ a neuronal-specific RNA-binding protein. ${ }^{5} \mathrm{HuD}$ expression increases during brain development, nerve regeneration, and learning and memory (Figure 2B), ${ }^{6}$ suggesting that this protein is important for controlling gene stabilization and would therefore also be important for maintaining elevated levels of GAP-43 mRNA during plasticity-associated processes. ${ }^{7}$ Overexpression of $\mathrm{HuD}$ results in a selective increase in GAP-43 mRNA in hippocampal dentate granule cells, neurons in the lateral amygdala, and layer $\mathrm{V}$ of the neocortex,${ }^{8}$ mimicking a state of high plasticity (Figure 2B). Experiments have shown that GAP-43 mRNA was more stable in brain extracts from $\mathrm{HuD}$ transgenic mice than in non-transgenic littermates, indicating that $\mathrm{HuD}$ can positively affect GAP-43 mRNA stability in vivo. ${ }^{8}$

The GAP-43 amino acid sequence is hydrophilic, ${ }^{9}$ with no membrane-spanning domains and no sites for glycosylation. ${ }^{10}$ There is a short hydrophobic amino acid sequence segment, indicating that the GAP-43 protein may be anchored on the cytoplasmic side of synaptic plasma membranes (see Figures 1 and 2A). ${ }^{10}$ Palmitoylation of 


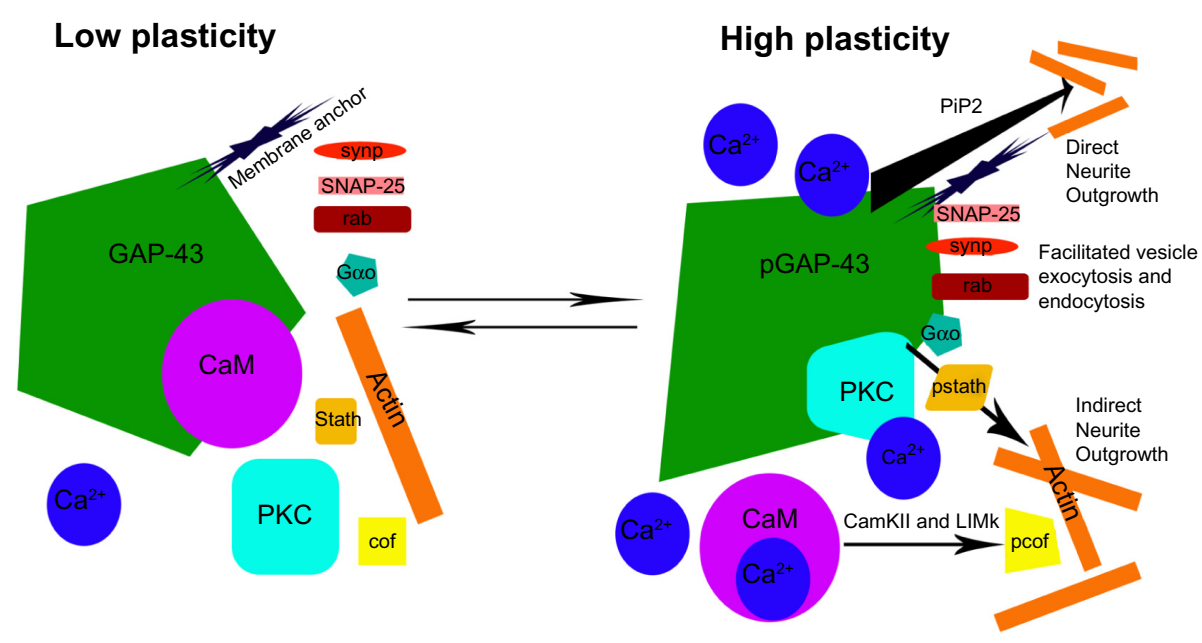

Figure I GAP-43 protein interactions during low- and high-plasticity states.

Notes: During conditions of low plasticity, GAP-43 remains bound with CaM in the presence of low calcium $\left(\mathrm{Ca}^{2+}\right)$. In conditions of high plasticity, elevated levels of $\mathrm{Ca}{ }^{2+}$ dissociate CaM from GAP-43, allowing phosphorylation by PKC. In this condition, direct neurite outgrowth can be enhanced via interactions with PiP2 and enhanced vesicle recycling (endocytosis and exocytosis) can be enhanced vie interactions with synp, rab, and SNAP-25. Enhanced neurite outgrowth is also facilitated by pGAP-43 via interactions with the GTP-binding protein, Go $(G o \alpha)$ and phosphorylation of pstath. Finally, an indirect effect on neurotic outgrowth occurs via release of CaM and pcof via CamKII and LIMk.

Abbreviations: CaM, calmodulin; LIMk, LIM kinase; PiP2, phosphatidylinositol 4,5-bisphosphate; PKC, protein kinase C; synp, synaptophysin; rab, rabatin; SNAP-25, synaptosomal-associated protein 25; pGAP-43, phosphorylated GAP-43; pstath, phosphorylated stathmin; pcof, phosphorylation of cofilin; CamKII, Ca ${ }^{2+} /$ calmodulindependent protein II.

Cys3 and Cys4 may be responsible for localization of the protein on the inner surface of plasma membranes (including growth cones), ${ }^{11}$ with initial palmitoylation occurring at the endoplasmic reticulum-Golgi intermediate compartment. ${ }^{12}$

Phosphorylation of GAP-43 is a major factor in its biochemical and physiological activity. The rat GAP-43 protein consists of 226 amino acids with a single phosphorylation site at Ser41 whereby PKC, ${ }^{13,14}$ and specifically, PKC-beta, ${ }^{15,16}$ can phosphorylate the protein (Figure 1). Calmodulin has been shown to inhibit GAP-43 phosphorylation by PKC (Figure 2A) ${ }^{9}$ and when the Ser41 site is changed to aspartate to mimic constitutive phosphorylation, calmodulin binding by GAP-43 is absent. ${ }^{17}$ GAP-43 is bound by calmodulin when $\mathrm{Ca}^{2+}$ levels are low and is released when $\mathrm{Ca}^{2+}$ levels rise (Figure 2A and $\mathrm{B}),{ }^{18}$ suggesting that calmodulin may act as a negative regulator of GAP-43 during periods of low activity in the neurons. ${ }^{19}$ One functional outcome of GAP-43 during activity-dependent increases in $\mathrm{Ca}^{2+}$ levels, when it is not bound by calmodulin, may be the regulation of exocytosis and endocytosis and synaptic vesicle recycling ${ }^{20}$ via interactions with synaptophysin, ${ }^{21,22}$ SNAP-25, ${ }^{23,24}$ and rabaptin-5 (Figures 1 and 2B). ${ }^{19,25}$ When calmodulin dissociates from GAP-43, it is free to interact with CamKII, $\mathrm{Ca}^{2+} /$ calmodulindependent protein II, leading to phosphorylation of cofilin by LIM kinases and neurite outgrowth. ${ }^{26,27}$

A number of other factors have been shown to modulate the phosphorylation of membrane-bound GAP-43. In the absence of $\mathrm{Ca}^{2+}$, arachidonic acid has been shown to exert a modest effect on the phosphorylation of GAP-43, while at $\mathrm{Ca}^{2+}$ levels likely to exist in the nerve terminal during enhanced plasticity, arachidonic acid (Figure 2B) can increase the sensitivity of GAP-43 phosphorylation to $\mathrm{Ca}^{2+}$ and increase the maximal level of phosphorylation by $50 \% .{ }^{28}$ The stimulatory effect of arachidonic acid and its synergistic interaction with $\mathrm{Ca}^{2+}$ are mediated by $\mathrm{PKC}$ (Figure 2B). ${ }^{28}$

\section{Neuroanatomical localization}

GAP-43 has been shown to be relatively neuron-specific (it has been detected in the plasma membranes of cultured neonatal rat cortical astrocyte ${ }^{29,30}$ ) with a high density in presynaptic terminals (although evidence suggests a potential role for GAP-43 in post-synaptic AMPA receptor trafficking ${ }^{31}$ ) in both the peripheral and central nervous systems. GAP-43 is expressed ubiquitously in the central nervous system at high levels during the perinatal period, with progressively restricted expression during maturation. ${ }^{32-34}$

GAP-43 remains present in the mature central nervous system in structures known to exhibit high plasticity, such as the cerebellum (granule cells ${ }^{35}$ but not Purkinje cells ${ }^{36}$ ), neocortex, entorhinal cortex, ${ }^{37}$ hippocampus, and olfactory bulb. ${ }^{38,39}$ Dense GAP-43 localization has specifically been shown in layer I of the cortex, the CA1 field of the hippocampus, ${ }^{40}$ but not granule cells, ${ }^{36,41}$ and in a subset of subcortical structures ${ }^{42}$ including the caudate putamen, olfactory tubercle, ${ }^{43}$ nucleus accumbens, bed nucleus of the 

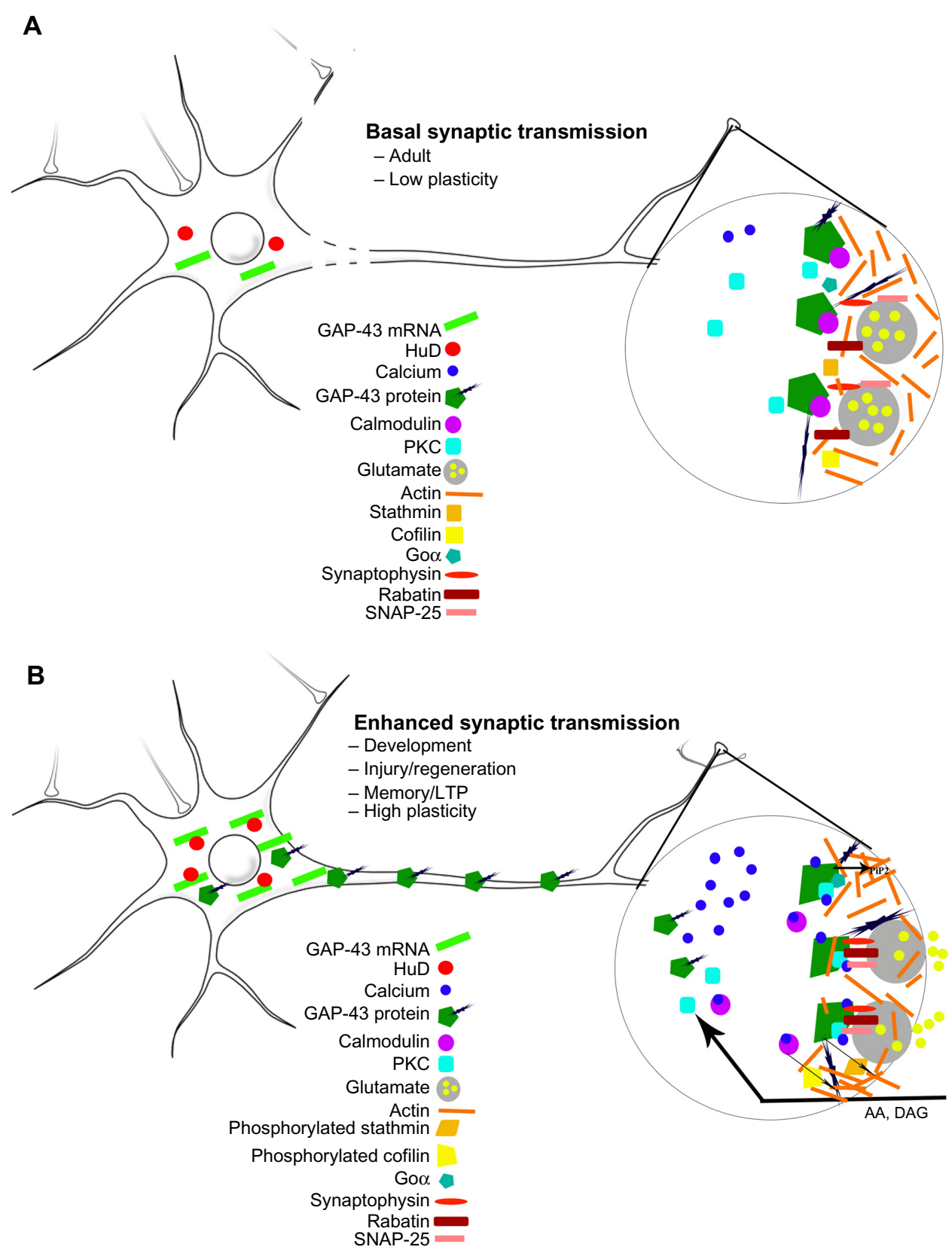

Figure 2 Functional aspects of GAP-43 in the neuron.

Notes: (A) During basal synaptic transmission, the HuD protein is not bound to GAP-43, decreasing its stability and keeping protein levels low. GAP-43 bound of CaM precludes its plasticity-permissive functions. (B) During high-plasticity states, HuD binds to and stabilizes GAP-43 mRNA, thereby elevating protein levels. In the presynaptic terminal, GAP-43 phosphorylation by PKC facilitates neurite outgrowth and vesicle recycling, thereby leading to enhanced neurotransmitter release (glutamate). This enhanced glutamate release liberates post-synaptic AA and DAG which can facilitate pre-synaptic phosphorylation of GAP-43.

Abbreviations: AA, arachidonic acid; CaM, calmodulin; DAG, diacylglycerol; LTP, long-term potentiation; PKC, protein kinase C; SNAP-25, synaptosomal-associated protein 25.

stria terminalis, amygdala, and medial preoptic area of the hypothalamus. ${ }^{44}$

Neurons containing biogenic amines such as the substantia nigra pars compacta (dopamine), the locus coeruleus (norepinephrine), and dorsal raphe (serotonin) exhibit intense GAP-43 staining. ${ }^{36,45,46}$ In cholinergic neurons, the medial septum, nucleus basalis magnocellularis, and the vertical limb of the diagonal band express intermediate levels, while the horizontal limb of the diagonal band and the substantia innominata express higher levels of GAP-43. ${ }^{47}$

Within the brainstem and spinal cord (such as spinal motor neurons ${ }^{48,49}$ ), GAP-43 is present at all vertebral levels, with higher concentrations in the cervical and thoracic regions. ${ }^{50}$ Densely myelinated regions are low in GAP-43, while unmyelinated or lightly myelinated areas, such as the substantia gelatinosa of the spinal cord and the nucleus of 
the solitary tract, express high levels of GAP-43. ${ }^{51}$ Electron microscopic examination has revealed that GAP-43 is localized in small myelinated and unmyelinated fibers and in terminals that make single axodendritic or axosomatic synapses. ${ }^{50}$ At this ultrastructural level, GAP-43 labeling is most prevalent in small unmyelinated axons (0.12-0.15 microns in diameter) and small (0.35 microns) axon terminals that contain round vesicles and form asymmetric synapses with thin spines. ${ }^{52}$

\section{Cellular localization}

GAP-43 is present throughout the neuron but at higher levels in axon terminals and growth cones. GAP-43 is absent from dendrites and myelinated axons, as indicated by double labeling with antibodies against microtubule-associated protein 2 and the large neurofilament protein. ${ }^{43,53}$ When cultured neurons begin to extend neurites, the cell body shows diffuse (decreased) GAP-43 staining while the growing tip of the neurites (ie, growth cone) shows elevated, punctate GAP-43 staining. ${ }^{14}$ That GAP-43 is localized to the inner surface of the growth cones was shown on positive immunostaining only after permeabilization of the plasma membrane. ${ }^{14}$ Showing its neuron-specificity, the GAP-43 antibody used did not label Schwann cells or fibroblasts. ${ }^{14}$

GAP-43 contributes to neuronal growth and nerve terminal plasticity. ${ }^{54}$ GAP-43 appears critical for stimulus-induced nerve sprouting at the neuromuscular junction; an effect that may occur via promotion of F-actin accumulation. ${ }^{55}$ GAP43 accumulates at subplasmalemmal rafts where it can regulate actin activity via modulation of $\mathrm{PI}(4,5) \mathrm{P} 2 .{ }^{56}$ Utilization of in vivo lentiviral-mediated gene silencing in the olivocerebellar system to downregulate GAP-43 climbing fibers resulted in atrophy of climbing fibers, measured as a decrease in length, branching, and number of synaptic boutons. ${ }^{57}$

\section{Relationship to development}

In animal studies, expression of GAP-43 during development appears to vary depending on brain region. ${ }^{58}$ In the cerebellum, GAP-43 mRNA expression appears to be critical in granule cell differentiation/migration and in parallel and climbing fiber axonal outgrowth and synaptogenesis. ${ }^{59}$ During development, cerebellar GAP-43 mRNA expression increases from birth to postnatal day (PND)7, then gradually declines during maturation. ${ }^{59}$ By PND21, GAP-43 mRNA expression is localized to the internal granule layer and the inferior olive, with minimal to no hybridization in the deep cerebellar nuclei and none in the molecular layer (similar to the adult). ${ }^{59}$ In the auditory brainstem, high levels of GAP-
43 protein are evident in all subdivisions of the cochlear nuclear complex and the superior olivary complex at PND0. ${ }^{60}$ Between PND8 and PND12, the GAP-43 staining pattern in these regions became punctate, indicating the formation of presynaptic endings. By PND16, the auditory brainstem nuclei appear mostly devoid of GAP-43 immunoreactivity, with the exception of staining localized to presynaptic terminals. ${ }^{60}$ In the cat visual cortex, phosphorylation of GAP-43 increased approximately 10-fold from PND1 to weeks 3-13 (the critical period of synaptic plasticity) then decreased to 2.5 -fold of PND1 by week 51.61 Protein quantification of GAP-43 in the cortex and hippocampus was elevated at PND14 and PND21 during an active period of synaptogenesis. ${ }^{62}$ Evidence from this study showed that GAP-43 is highly expressed in immature growing axonal terminals with decreased expression during the maturation process, showing an inverse relationship with synapsin or synaptotagmin expression. ${ }^{62}$ In the optic nerve and optic fiber layer of the retina, GAP-43 staining was high at PND0 then disappeared between PND8 and PND16. ${ }^{63}$

At the developmental cellular level, GAP-43 appears to be involved in neurite outgrowth via the amplification of pathfinding signals from the growth cone. ${ }^{64}$ Six days after plating cells, GAP-43 labeling was shown to be clustered in growth cones, and by 10 days cell body labeling was lost, while at 20 days the neuritic and growth cone labeling was reduced. ${ }^{65}$ GAP-43 expression in adult olfactory neurons resulted in numerous primary olfactory axons with enlarged endings, providing in vivo evidence for a role of GAP-43 in nerve fiber formation and axon morphology determination. ${ }^{66}$ The level of GAP-43 expression and axonal growth during development may be dually controlled by activity-independent transcriptional processes and by activity-dependent, N-methyl-Daspartate (NMDA) receptor-mediated post-transcriptional mechanisms. ${ }^{67}$

Several factors have been shown to interact with GAP-43 during neurite outgrowth. In PC12 pheochromocytoma cells, induction of a neuronal phenotype by nerve growth factor is accompanied by a marked increase in GAP-43 levels. ${ }^{68}$ Induction of GAP-43 by nerve growth factor is apparent after 3 hours of exposure and reaches maximal levels at 24 hours. ${ }^{69}$ GAP-43-transfected PC12 cells show an enhanced response to nerve growth factor, suggesting that GAP-43 may respond to extrinsic growth factors to modulate neurite extension. ${ }^{70}$ Neural cell adhesion molecule (NCAM)-mediated fibroblast growth factor receptor activation in cerebellar granule cells is associated with increased GAP-43 phosphorylation on Ser41 and neurite 
outgrowth, whereas neither NCAM nor fibroblast growth factor was able to stimulate neurite outgrowth following GAP-43 gene deletion. ${ }^{71}$ Newly formed synapses show a dramatic decrease in palmitoylation of GAP-43 early in the critical period, ${ }^{72}$ which may be sufficient to stop advancing axons, suggesting a developmental switch for GAP-43 $\mathrm{S}$-palmitoylation that may be required to disengage the molecular machinery for axon extension. ${ }^{72}$ GAP-43 has been shown to amplify extracellular signals via an interaction with the GTP-binding protein, Go (Figures 1 and 2B), increasing the sensitivity of Go, thereby altering the predilection for neuronal outgrowth. ${ }^{73-75}$

\section{Relationship to regeneration}

GAP-43 synthesis is upregulated in association with nerve regeneration, potentially recapitulating an early developmental program. ${ }^{3}$ While endogenous GAP-43 is downregulated in mouse motor nerves and neuromuscular junctions during the second postnatal week, it is re-expressed during regeneration and potentiates nerve sprouting. ${ }^{76}$ After cutting or crushing the sciatic nerve in adult rats in vivo, it takes 3 days for GAP-43 immunoreactivity to appear in the axotomized dorsal root ganglion cells followed by transport into the newly formed sprouts. ${ }^{77,78}$ The intensity of staining peaks at 21 days and becomes undetectable 9 weeks following crush injury and 36 weeks following cutting of the sciatic nerve. ${ }^{78}$ Downregulation of GAP-43 was reported to result in a significant decrease in newly formed branches in climbing fibers after laser axotomy. GAP-43 mRNA downregulation also hampered the generation of reactive sprouts, showing a requirement for GAP-43 in promoting the initiation of axonal regrowth after axotomy. ${ }^{79}$

GAP-43 mRNA and protein increase following peripheral deafferentation of the olfactory epithelium and after olfactory bulbectomy, and are associated with formation of immature olfactory receptor neurons. ${ }^{80}$ GAP-43 immunoreactivity was shown to be increased 3 weeks after binocular retinal lesions in adult cats in the part of the dorsal lateral geniculate nucleus that represents this region of the retina. ${ }^{81}$ Following axotomy in the medial forebrain bundle, GAP-43 immunoreactivity is associated with catecholaminergic and serotonergic axonal sprouts that regenerate around the surgical lesion. ${ }^{82}$ Removal of cochlear neurons in adult rats leads to emergence of GAP-43 immunoreactivity in varicose fibers of the ipsilateral ventral cochlear nucleus and cell bodies of the lateral superior olive. ${ }^{83}$ Following stroke, optogenetic neuronal stimulation in the ipsilesional primary motor cortex promotes functional recovery associated with improved cerebral blood flow and increased expression of numerous activity-dependent neurotrophins, such as brain-derived neurotrophic factor, nerve growth factor, and GAP-43. ${ }^{84}$

In the adult rat brain, levels of GAP-43 immunoreactivity in layer IV of the barrel receptor field are moderate in the interbarrel septa and low within the barrels themselves. ${ }^{85}$ Changes in the pattern of GAP-43 immunoreactivity were analyzed 1-8 weeks after unilateral vibrissectomy to examine the effect and time course of removal of all but the $\mathrm{C} 3$ vibrissa on GAP-43 immunoreactivity. The $\mathrm{C} 3$ area that was GAP-43-immunonegative showed a decrease in total area from $8.4 \% 1$ week after vibrissectomy to a $12 \%$ decrease 8 weeks after surgery relative to the control ipsilateral cortex. This suggests a GAP-43-mediated axonal sprouting process within the barrel cortex, whereby GAP-43-positive terminals encroach on areas of GAP-43 absence. ${ }^{85}$ In a second study, GAP-43 mRNA was analyzed in the barrel cortex in adult rats that underwent unilateral vibrissectomy with sparing of the $\mathrm{C} 3$ vibrissa. ${ }^{86}$ GAP-43 levels were elevated by $25 \%$ compared with the non-lesioned side for 6 days following surgery, then decreased to $88 \%$ at 7 days and returned to control levels by 14 days. $^{86}$

Reports have revealed alterations in the pattern of GAP-43 protein levels in the hippocampus during reactive synaptogenesis following lesions of the perforant pathway. ${ }^{70}$ Changes in the synthesis and transport of GAP-43 in entorhinal cortex neurons and the perforant pathway were assessed during lesion-induced sprouting and reactive synaptogenesis. ${ }^{87}$ Following unilateral entorhinal cortex lesions in adult rats, there was a 2 -fold (100\%) increase in transport of newly synthesized GAP-43 to the contralateral or "sprouting" hippocampus. This upregulation occurred between 6 and 15 days after damage and coincided with the growth of presynaptic terminals during sprouting. ${ }^{87}$

Aside from structural/neuronal damage leading to reactive axonal sprouting and associated elevations in GAP-43, the excitotoxicity process can lead to GAP-43-dependent sprouting independent of neuronal damage. In one such study, ${ }^{88}$ hypersynchronous activity in the hippocampus led to expression of GAP-43 mRNA in dentate gyrus granule cells followed by reactive sprouting in the granule cell axons (also known as mossy fibers). Twelve hours after subcutaneous injection of kainate, GAP-43 mRNA expression was evident in granule cells (where expression is normally absent in the adult brain), and 2 days after treatment (up to 40 days), GAP-43 protein immunoreactivity and mossy fiber sprouting within the supragranular layer were observed. As stated, these events are similar to those seen after neuronal damage 
leading to axonal regeneration, with one difference being that granule cell axons were not damaged by kainite. ${ }^{88}$

\section{Relationship to long-term potentiation (LTP)}

One cellular process underlying synaptic plasticity is LTP, which has been shown to engage, and be intricately related to, alterations in GAP-43 levels and phosphorylation. ${ }^{89}$ In the intact rat hippocampus, there was a selective increase in the in vitro phosphorylation state of GAP-43 5 minutes after induction of LTP that was directly related to the change in synaptic efficiency. ${ }^{90}$ Low-frequency, non-potentiating stimulation resulted in no change in GAP-43 phosphorylation. In vivo phosphorylation of GAP-43 was increased in the synaptic membranes of the mossy fiber CA3 pyramidal neurons at 1 and 5 minutes after tetanic stimulation, but not at 60 minutes, suggesting a role for GAP-43 phosphorylation in the induction but not maintenance of LTP at the mossy fiber synapse. ${ }^{91}$ This GAP-43 phosphorylation was shown to occur independent of the NMDA receptor, to be mediated by PKC, and to be inhibited in the presence of calmodulin. ${ }^{91}$ Dorsal hippocampal tissue extracted from animals 3 days following induction of LTP in granule cells by stimulation of the perforant pathway showed enhanced phosphorylation of GAP-43 compared with tissue from lowfrequency stimulated controls..$^{92}$ Perforant path LTP in the intact mouse hippocampal dentate gyrus increased GAP-43 mRNA in hilar cells 3 days after tetanus, but not in granule cells. ${ }^{93}$ The LTP-induced GAP-43 mRNA elevation in hilar cells was positively correlated with the level of potentiation and blocked by pretreatment with the NMDA receptor antagonist, DL-aminophosphonovalerate. ${ }^{93}$ The phosphorylation state of GAP-43 was monitored after induction of LTP in the CA1 field in rat hippocampal slices and revealed increased phosphorylation 10-60 minutes following LTP induction but not after 90 minutes. ${ }^{94}$ The increased GAP-43 phosphorylation was not observed when LTP was blocked with DL-aminophosphonovalerate or when tetanic stimulation failed to induce LTP. ${ }^{94,95}$ At 1 hour, but not at 2 hours after LTP, GAP-43, and PKC-gamma mRNA hybridization were increased..$^{96}$ A related study showed decreased levels of GAP-43 gene expression in the CA3 subfield and both PKC-beta and PKC-gamma 3 days after LTP induction. ${ }^{97}$ Alterations in GAP-43 mRNA and PKC-gamma were highly correlated. The authors suggested that lowered expression of GAP-43 at 3 days would reduce potential growth, leading to synaptic stabilization in stimulated pathways. ${ }^{97}$ Injection of monoclonal antibodies that inhibited PKC phosphorylation of GAP-43 was shown to prevent induction of LTP in CA1 pyramidal neurons in rat hippocampal slices. ${ }^{98}$

Overexpression of a constitutively phosphorylated form of GAP-43 results in an enhancement of LTP in hippocampal slices in the CA1 region associated with an increase in presynaptic paired-pulse facilitation..$^{99}$ LTP enhancement was not observed in transgenic mice overexpressing a nonphosphorylatable form of GAP-43 nor in GAP-43-deficient mice. ${ }^{99}$ Others have suggested that presynaptic phosphorylation of GAP-43 may be affected by retrograde messengers produced postsynaptically following NMDA receptor activation that diffuse to activate PKC. ${ }^{100}$ In this regard, application of arachidonic acid at concentrations that produce LTP significantly increased translocation of PKC immunoreactivity from cytosol to membrane and phosphorylated GAP-43 observed in hippocampal synaptosomes, suggesting that arachidonic acid may contribute to LTP maintenance by activation of presynaptic PKC and phosphorylation of GAP-43 (Figure 2B). ${ }^{100}$

\section{Relationship to memory storage}

Given the relationship of GAP-43 with LTP, it is of no surprise that changes in levels of GAP-43 (whether decrements or increments) have been shown to be associated with memory storage processes in adult animals. In one such example, heterozygous GAP-43 knockout mice with GAP-43 levels reduced by one half showed impaired memory for a shock-paired context. ${ }^{101}$ In this study, there were no decrements in cued shock-conditioning nor decrements on tests of nociceptive or auditory perception, indicating that the contextual memory impairment was not based on impaired sensory or performance factors. ${ }^{101}$ Using a similar behavioral procedure (contextual fear conditioning), sustained phosphorylation of GAP-43 in the hippocampus was noted for 1.5-72 hours after training. ${ }^{102}$ At early time points after contextual fear conditioning training (15-90 minutes), PKC-alpha and PKC-gamma translocated to the membrane, while PKC-betaII and PKC-epsilon moved more transiently (15-30 minutes) to the cytosol. ${ }^{102}$

Three lines of transgenic mice have been developed, each with a particular manipulation of the PKC phosphorylation site: ${ }^{103} \mathrm{G}$-Phos overexpresses the phosphorylatable and dephosphorylatable form of chick GAP-43 (the native protein; no mutation); G-Perm overexpresses chick GAP-43 that is permanently pseudophosphorylated; and GNonP overexpresses nonphosphorylatable GAP-43. The overall behavioral memory functions associated with each of these lines has been reported; ${ }^{104}$ G-Phos mice showed enhanced 
spatial flexibility on a water maze task; G-Perm mice showed memory persistence as evidenced by their inability to extinguish a classically conditioned fear response; and G-NonP mice showed retention deficits in their ability to recall spatial information on a water maze task. In another study, G-Phos mice alone were more fully tested for their ability on the water maze spatial task. ${ }^{105}$ These G-Phos mice could be divided at the behavioral level into "spatial bright" and "spatial dull" groups based on their water maze task performance and GAP-43 protein levels in the hippocampus. G-Phos dull mice showed both acquisition and retention deficits on the fixed hidden platform task, but were able to learn a visible platform task while G-Phos bright mice showed memory enhancement relative to wild-type on a more difficult movable hidden platform spatial memory task. In the hippocampus, the G-Phos dull group showed a 50\% greater transgenic GAP-43 protein level and a 2-fold elevated transgenic GAP-43 mRNA level than that measured in the G-Phos bright group. While overexpression of GAP-43 would normally be predicted to enhance memory function, in the case of G-Phos dull mice, it could be the case that high levels of GAP-43 protein aggregate in presynaptic terminals leading to impoverished synaptic vesicle recycling, deficient neurotransmitter release, and impaired memory function.

Two other studies have examined the relationship of GAP-43 levels with neuronal restructuring after memory formation. In the first study, rats that were tested for their retention of a spatial memory task after a 30-day delay exhibited increased GAP-43 labeling in the anterior cingulate cortex as compared with the 1-day retention group. ${ }^{106}$ In a second study, mice were trained for 5 days on one of three different versions of the water maze task. High-resolution magnetic resonance imaging analysis revealed structural expansion in the hippocampus of mice trained on the spatial version of the task that was correlated with GAP-43 protein staining. ${ }^{107}$

\section{Relationship to drug-induced synaptic plasticity}

Changes in phosphorylation of GAP-43 have been demonstrated in other forms of behavioral plasticity, such as those associated with drug use. ${ }^{108}$ Following one injection of amphetamine, GAP-43 phosphorylation was increased in rat striatum and persisted for 1 week. ${ }^{109}$ In cultured PC12 cells, repeated intermittent amphetamine treatment ( 5 minutes a day for 5 days) induced neurite outgrowth that was associated with an increase in the level of GAP-43 staining. ${ }^{110} \mathrm{~A}$ single exposure to cocaine $20 \mathrm{mg} / \mathrm{kg}$ induced locomotor sensitization to an injection of cocaine $10 \mathrm{mg} / \mathrm{kg}$ that was observed at
24 hours, 48 hours, and 7 days, with an associated increase in mRNA GAP-43 in the shell and core subregions of the nucleus accumbens and in the ventral tegmental area. ${ }^{111}$ Administration of a single intraperitoneal dose of ethanol $(2.5 \mathrm{~g} / \mathrm{kg}, 15 \%$ in saline) resulted in a decrease in GAP-43 mRNA level 2 hours after administration, with subsequent decreased GAP-43 and phosphorylated GAP-43 immunoreactivity 4 hours after administration in the perforant and mossy fiber pathways. ${ }^{12}$

\section{Conclusion}

Activity of GAP-43, whether mRNA elevations or phosphorylation of the protein, is intricately involved in presynaptic plasticity as occurs during developmental outgrowth of neurites, elevated following neuronal injury in the course of axonal regeneration, and tightly linked with memory processes for the period of reorganization of neural networks. These functions are in part due to regulation and distribution of GAP-43 mRNA at the molecular level and PKC-dependent phosphorylation at the biochemical level. Utilization of this knowledge may open up future directions for targeted treatments of developmental disorders, memory dysfunction, and neuronal injury.

\section{Disclosure}

The author reports no conflicts of interest in this work.

\section{References}

1. Snipes GJ, Chan SY, McGuire CB, et al. Evidence for the coidentification of GAP-43, a growth-associated protein, and F1, a plasticity-associated protein. J Neurosci. 1987;7(12):4066-4075.

2. Grabczyk E, Zuber MX, Federoff HJ, Ng SC, Pack A, Fishman MC. Cloning and characterization of the rat gene encoding GAP-43. Eur $J$ Neurosci. 1990;2(10):822-827.

3. Benowitz LI, Routtenberg A. GAP-43: an intrinsic determinant of neuronal development and plasticity. Trends Neurosci. 1997;20(2):84-91.

4. Sanna MD, Quattrone A, Mello T, Ghelardini C, Galeotti N. The RNA-binding protein $\mathrm{HuD}$ promotes spinal GAP43 overexpression in antiretroviral-induced neuropathy. Exp Neurol. 2014;261:343-353.

5. Mobarak CD, Anderson KD, Morin M, et al. The RNA-binding protein $\mathrm{HuD}$ is required for GAP-43 mRNA stability, GAP-43 gene expression, and PKC-dependent neurite outgrowth in PC12 cells. Mol Biol Cell. 2000;11(9):3191-3203.

6. Deschenes-Furry J, Mousavi K, Bolognani F, et al. The RNA-binding protein $\mathrm{HuD}$ binds acetylcholinesterase mRNA in neurons and regulates its expression after axotomy. J Neurosci. 2007;27(3):665-675.

7. Perrone-Bizzozero N, Bolognani F. Role of HuD and other RNAbinding proteins in neural development and plasticity. $J$ Neurosci Res. 2002;68(2):121-126.

8. Bolognani F, Tanner DC, Merhege M, Deschenes-Furry J, Jasmin B, Perrone-Bizzozero NI. In vivo post-transcriptional regulation of GAP-43 mRNA by overexpression of the RNA-binding protein $\mathrm{HuD}$. J Neurochem. 2006;96(3):790-801.

9. Chan SY, Murakami K, Routtenberg A. Phosphoprotein F1: purification and characterization of a brain kinase $\mathrm{C}$ substrate related to plasticity. J Neurosci. 1986;6(12):3618-3627. 
10. Basi GS, Jacobson RD, Virag I, Schilling J, Skene JH. Primary structure and transcriptional regulation of GAP-43, a protein associated with nerve growth. Cell. 1987;49(6):785-791.

11. Strittmatter SM, Valenzuela D, Fishman MC. An amino-terminal domain of the growth-associated protein GAP-43 mediates its effects on filopodial formation and cell spreading. J Cell Sci. 1994;107 Pt 1: 195-204.

12. McLaughlin RE, Denny JB. Palmitoylation of GAP-43 by the ER-Golgi intermediate compartment and Golgi apparatus. Biochim Biophys Acta. 999;1451(1):82-92.

13. Coggins PJ, Zwiers H. Evidence for a single protein kinase C-mediated phosphorylation site in rat brain protein B-50. J Neurochem. 1989;53(6): 1895-1901.

14. Meiri KF, Willard M, Johnson MI. Distribution and phosphorylation of the growth-associated protein GAP-43 in regenerating sympathetic neurons in culture. $J$ Neurosci. 1988;8(7):2571-2581.

15. Sheu FS, Marais RM, Parker PJ, Bazan NG, Routtenberg A. Neuronspecific protein F1/GAP-43 shows substrate specificity for the beta subtype of protein kinase C. Biochem Biophys Res Commun. 1990;171(3): $1236-1243$.

16. Rosenthal A, Chan SY, Henzel W, et al. Primary structure and mRNA localization of protein $\mathrm{F} 1$, a growth-related protein kinase $\mathrm{C}$ substrate associated with synaptic plasticity. EMBO J. 1987;6(12):3641-3646.

17. Chao S, Benowitz LI, Krainc D, Irwin N. Use of a two-hybrid system to investigate molecular interactions of GAP-43. Brain Res Mol Brain Res. 996;40(2):195-202.

18. Kumar V, Chichili VP, Zhong L, et al. Structural basis for the interaction of unstructured neuron specific substrates neuromodulin and neurogranin with calmodulin. Sci Rep. 2013;3:1392.

19. Neve RL, Coopersmith R, McPhie DL, et al. The neuronal growthassociated protein GAP-43 interacts with rabaptin-5 and participates in endocytosis. J Neurosci. 1998;18(19):7757-7767.

20. Cousin MA. Synaptic vesicle endocytosis: calcium works overtime in the nerve terminal. Mol Neurobiol. 2000;22(1-3):115-128.

21. Hou XE, Dahlstrom A. Synaptic vesicle proteins and neuronal plasticity in adrenergic neurons. Neurochem Res. 2000;25(9-10):1275-1300.

22. Verkade P, Verkleij AJ, Annaert WG, Gispen WH, Oestreicher AB. Ultrastructural localization of B-50/growth-associated protein-43 to anterogradely transported synaptophysin-positive and calcitonin generelated peptide-negative vesicles in the regenerating rat sciatic nerve. Neuroscience. 1996;71(2):489-505.

23. Rekart JL, Routtenberg A. Overexpression of GAP-43 reveals unexpected properties of hippocampal mossy fibers. Hippocampus. 2010;20(1):46-57.

24. Goutan E, Marti E, Ferrer I. Expression of synaptic proteins in the developing rat cerebellum following ionizing radiation. Int $J$ Dev Neurosci. 1999; 17(4):275-283.

25. Chia PH, Li P, Shen K. Cell biology in neuroscience: cellular and molecular mechanisms underlying presynapse formation. J Cell Biol. 2013;203(1):11-22.

26. Arber S, Barbayannis FA, Hanser H, et al. Regulation of actin dynamics through phosphorylation of cofilin by LIM-kinase. Nature. 1998;393(6687):805-809.

27. Heng JI, Chariot A, Nguyen L. Molecular layers underlying cytoskeletal remodelling during cortical development. Trends Neurosci. 2010;33(1): $38-47$.

28. Schaechter JD, Benowitz LI. Activation of protein kinase C by arachidonic acid selectively enhances the phosphorylation of GAP-43 in nerve terminal membranes. J Neurosci. 1993;13(10):4361-4371.

29. Vitkovic L, Steisslinger HW, Aloyo VJ, Mersel M. The 43-kDa neuronal growth-associated protein (GAP-43) is present in plasma membranes of rat astrocytes. Proc Natl Acad Sci U S A. 1988;85(21):8296-8300.

30. Vitkovic L, Mersel M. Growth-associated protein 43 is down-regulated in cultured astrocytes. Metab Brain Dis. 1989;4(1):47-53.

31. Han MH, Jiao S, Jia JM, et al. The novel caspase-3 substrate Gap43 is involved in AMPA receptor endocytosis and long-term depression. Mol Cell Proteomics. 2013;12(12):3719-3731.
32. Chao HM, Spencer RL, Sakai RR, McEwen BS. The expression of growthassociated protein GAP-43 mRNA in the rat hippocampus in response to adrenalectomy and aging. Mol Cell Neurosci. 1992;3(6):529-535.

33. Barnes CA, Mizumori SJ, Lovinger DM, et al. Selective decline in protein F1 phosphorylation in hippocampus of senescent rats. Neurobiol Aging. 1988;9(4):393-398.

34. Casoli T, Spagna C, Fattoretti P, Gesuita R, Bertoni-Freddari C. Neuronal plasticity in aging: a quantitative immunohistochemical study of GAP-43 distribution in discrete regions of the rat brain. Brain Res. 1996;714(1-2):111-117.

35. Casoli T, Di Stefano G, Gracciotti N, et al. Cellular distribution of GAP-43 mRNA in hippocampus and cerebellum of adult rat brain by in situ RT-PCR. J Histochem Cytochem. 2001;49(9):1195-1196.

36. Meberg PJ, Routtenberg A. Selective expression of protein F1/ (GAP-43) mRNA in pyramidal but not granule cells of the hippocampus. Neuroscience. 1991;45(3):721-733.

37. Kruger L, Bendotti C, Rivolta R, Samanin R. GAP-43 mRNA localization in the rat hippocampus CA3 field. Brain Res Mol Brain Res. 1992;13(3):267-272.

38. McGuire CB, Snipes GJ, Norden JJ. Light-microscopic immunolocalization of the growth- and plasticity-associated protein GAP-43 in the developing rat brain. Brain Res. 1988;469(1-2):277-291.

39. De la Monte SM, Federoff HJ, Ng SC, Grabczyk E, Fishman MC. GAP-43 gene expression during development: persistence in a distinctive set of neurons in the mature central nervous system. Brain Res Dev Brain Res. 1989;46(2):161-168.

40. Casoli T, Stefano GD, Fattoretti P, et al. GAP-43 mRNA detection by in situ hybridization, direct and indirect in situ RT-PCR in hippocampal and cerebellar tissue sections of adult rat brain. Micron. 2003;34(8): 415-422.

41. McNamara RK, Lenox RH. Comparative distribution of myristoylated alanine-rich $\mathrm{C}$ kinase substrate (MARCKS) and F1/GAP-43 gene expression in the adult rat brain. J Comp Neurol. 1997;379(1):48-71.

42. Rosskothen-Kuhl N, Illing RB. Gap43 transcription modulation in the adult brain depends on sensory activity and synaptic cooperation. PLoS One. 2014;9(3):e92624.

43. Ramakers GJ, Verhaagen J, Oestreicher AB, Margolis FL, van Bergen en Henegouwen PM, Gispen WH. Immunolocalization of B-50 (GAP-43) in the mouse olfactory bulb: predominant presence in preterminal axons. J Neurocytol. 1992;21(12):853-869.

44. Benowitz LI, Apostolides PJ, Perrone-Bizzozero N, Finklestein SP, Zwiers $\mathrm{H}$. Anatomical distribution of the growth-associated protein GAP-43/B-50 in the adult rat brain. J Neurosci. 1988;8(1):339-352.

45. Bendotti C, Servadio A, Samanin R. Distribution of GAP-43 mRNA in the brain stem of adult rats as evidenced by in situ hybridization: localization within monoaminergic neurons. J Neurosci. 1991;11(3): 600-607.

46. Kruger L, Bendotti C, Rivolta R, Samanin R. Distribution of GAP-43 mRNA in the adult rat brain. J Comp Neurol. 1993;333(3):417-434.

47. McKinney M, Kent C. Differential expression of GAP-43 mRNA in adult central cholinergic neuronal populations. Brain Res Mol Brain Res. 1994;23(3):213-220.

48. Berg A, Zelano J, Stephan A, et al. Reduced removal of synaptic terminals from axotomized spinal motoneurons in the absence of complement C3. Exp Neurol. 2012;237(1):8-17.

49. Gordon T, You S, Cassar SL, Tetzlaff W. Reduced expression of regeneration associated genes in chronically axotomized facial motoneurons. Exp Neurol. 2015;264:26-32.

50. Curtis R, Averill S, Priestley JV, Wilkin GP. The distribution of GAP-43 in normal rat spinal cord. J Neurocytol. 1993;22(1):39-50.

51. Kapfhammer JP, Schwab ME. Inverse patterns of myelination and GAP-43 expression in the adult CNS: neurite growth inhibitors as regulators of neuronal plasticity? J Comp Neurol. 1994;340(2):194-206.

52. DiFiglia M, Roberts RC, Benowitz LI. Immunoreactive GAP-43 in the neuropil of adult rat neostriatum: localization in unmyelinated fibers, axon terminals, and dendritic spines. J Comp Neurol. 1990;302(4):992-1001. 
53. Carriel V, Garzon I, Campos A, Cornelissen M, Alaminos M. Differential expression of GAP-43 and neurofilament during peripheral nerve regeneration through bio-artificial conduits. J Tissue Eng Regen Med. July 31, 2014. [Epub ahead of print.]

54. He Q, Dent EW, Meiri KF. Modulation of actin filament behavior by GAP-43 (neuromodulin) is dependent on the phosphorylation status of serine 41, the protein kinase C site. J Neurosci. 1997;17(10):3515-3524.

55. Frey D, Laux T, Xu L, Schneider C, Caroni P. Shared and unique roles of CAP23 and GAP43 in actin regulation, neurite outgrowth, and anatomical plasticity. J Cell Biol. 2000;149(7):1443-1454.

56. Laux T, Fukami K, Thelen M, Golub T, Frey D, Caroni P. GAP43, MARCKS, and CAP23 modulate $\mathrm{PI}(4,5) \mathrm{P}(2)$ at plasmalemmal rafts, and regulate cell cortex actin dynamics through a common mechanism. J Cell Biol. 2000;149(7):1455-1472.

57. Grasselli G, Mandolesi G, Strata P, Cesare P. Impaired sprouting and axonal atrophy in cerebellar climbing fibres following in vivo silencing of the growth-associated protein GAP-43. PLoS One. 2011; 6(6):e20791.

58. Onodera N, Kakehata A, Araki I. Differential expression of GAP-43 protein in the rostral brain neurons of early chick embryos. Tohoku $J$ Exp Med. 2013;231(4):293-298.

59. Console-Bram LM, Fitzpatrick-McElligott SG, McElligott JG Distribution of GAP-43 mRNA in the immature and adult cerebellum: a role for GAP-43 in cerebellar development and neuroplasticity. Brain Res Dev Brain Res. 1996;95(1):97-106.

60. Horvath M, Forster CR, Illing RB. Postnatal development of GAP-43 immunoreactivity in the auditory brainstem of the rat. J Comp Neurol. 1997;382(1):104-115.

61. Sheu FS, Kasamatsu T, Routtenberg A. Protein kinase C activity and substrate (F1/GAP-43) phosphorylation in developing cat visual cortex. Brain Res. 1990;524(1):144-148.

62. Morita S, Miyata S. Synaptic localization of growth-associated protein 43 in cultured hippocampal neurons during synaptogenesis Cell Biochem Funct. 2013;31(5):400-411.

63. Kapfhammer JP, Christ F, Schwab ME. The expression of GAP-43 and synaptophysin in the developing rat retina. Brain Res Dev Brain Res. 1994;80(1-2):251-260.

64. Strittmatter SM, Fankhauser C, Huang PL, Mashimo H, Fishman MC. Neuronal pathfinding is abnormal in mice lacking the neuronal growth cone protein GAP-43. Cell. 1995;80(3):445-452.

65. Burry RW, Lah JJ, Hayes DM. Redistribution of GAP-43 during growth cone development in vitro; immunocytochemical studies. J Neurocytol. 1991;20(2):133-144.

66. Holtmaat AJ, Dijkhuizen PA, Oestreicher AB, et al. Directed expression of the growth-associated protein B-50/GAP-43 to olfactory neurons in transgenic mice results in changes in axon morphology and extraglomerular fiber growth. J Neurosci. 1995;15(12):7953-7965.

67. Cantallops I, Routtenberg A. Activity-dependent regulation of axonal growth: posttranscriptional control of the GAP-43 gene by the NMDA receptor in developing hippocampus. J Neurobiol. 1999;41(2): 208-220

68. Irwin N, Chao S, Goritchenko L, et al. Nerve growth factor controls GAP-43 mRNA stability via the phosphoprotein ARPP-19. Proc Natl Acad Sci U S A. 2002;99(19):12427-12431.

69. Costello B, Meymandi A, Freeman JA. Factors influencing GAP-43 gene expression in PC12 pheochromocytoma cells. J Neurosci. 1990;10(4):1398-1406.

70. Neve RL, Ivins KJ, Benowitz LI, During MJ, Geller AI. Molecular analysis of the function of the neuronal growth-associated protein GAP-43 by genetic intervention. Mol Neurobiol. 1991;5(2-4):131-141.

71. Meiri KF, Saffell JL, Walsh FS, Doherty P. Neurite outgrowth stimulated by neural cell adhesion molecules requires growth-associated protein-43 (GAP-43) function and is associated with GAP-43 phosphorylation in growth cones. J Neurosci. 1998;18(24):10429-10437.

72. Patterson SI, Skene JH. A shift in protein S-palmitoylation, with persistence of growth-associated substrates, marks a critical period for synaptic plasticity in developing brain. J Neurobiol. 1999;39(3):423-437.
73. Strittmatter SM, Valenzuela D, Vartanian T, Sudo Y, Zuber MX, Fishman MC. Growth cone transduction: Go and GAP-43. J Cell Sci Suppl. 1991;15:27-33.

74. Strittmatter SM, Igarashi M, Fishman MC. GAP-43 amino terminal peptides modulate growth cone morphology and neurite outgrowth. J Neurosci. 1994;14(9):5503-5513.

75. Strittmatter SM, Cannon SC, Ross EM, Higashijima T, Fishman MC. GAP-43 augments G protein-coupled receptor transduction in Xenopus laevis oocytes. Proc Natl Acad Sci U S A. 1993;90(11):5327-5331.

76. Caroni P, Aigner L, Schneider C. Intrinsic neuronal determinants locally regulate extrasynaptic and synaptic growth at the adult neuromuscular junction. J Cell Biol. 1997;136(3):679-692.

77. Gispen WH, Boonstra J, De Graan PN, et al. B-50/GAP-43 in neuronal development and repair. Restor Neurol Neurosci. 1990;1(3): 237-244.

78. Woolf CJ, Reynolds ML, Molander C, O’Brien C, Lindsay RM, Benowitz LI. The growth-associated protein GAP-43 appears in dorsal root ganglion cells and in the dorsal horn of the rat spinal cord following peripheral nerve injury. Neuroscience. 1990;34(2):465-478.

79. Allegra Mascaro AL, Cesare P, Sacconi L, et al. In vivo single branch axotomy induces GAP-43-dependent sprouting and synaptic remodeling in cerebellar cortex. Proc Natl Acad Sci U S A. 2013;110(26): 10824-10829.

80. Verhaagen J, Oestreicher AB, Grillo M, Khew-Goodall YS, Gispen WH, Margolis FL. Neuroplasticity in the olfactory system: differential effects of central and peripheral lesions of the primary olfactory pathway on the expression of B-50/GAP43 and the olfactory marker protein. J Neurosci Res. 1990;26(1):31-44.

81. Baekelandt V, Arckens L, Annaert W, Eysel UT, Orban GA, Vandesande F. Alterations in GAP-43 and synapsin immunoreactivity provide evidence for synaptic reorganization in adult cat dorsal lateral geniculate nucleus following retinal lesions. Eur J Neurosci. 1994;6(5): 754-765.

82. Alonso G, Ridet JL, Oestreicher AB, Gispen WH, Privat A. B-50 (GAP-43) immunoreactivity is rarely detected within intact catecholaminergic and serotonergic axons innervating the brain and spinal cord of the adult rat, but is associated with these axons following lesion. Exp Neurol. 1995;134(1):35-48.

83. Illing RB, Horvath M. Re-emergence of GAP-43 in cochlear nucleus and superior olive following cochlear ablation in the rat. Neurosci Lett. 1995;194(1-2):9-12.

84. Cheng MY, Wang EH, Woodson WJ, et al. Optogenetic neuronal stimulation promotes functional recovery after stroke. Proc Natl Acad Sci U S A. 2014;111(35):12913-12918.

85. Dunn-Meynell AA, Benowitz LI, Levin BE. Vibrissectomy induced changes in GAP-43 immunoreactivity in the adult rat barrel cortex. J Comp Neurol. 1992;315(2):160-170.

86. Levin BE, Dunn-Meynell A. Regulation of growth-associated protein 43 (GAP-43) messenger RNA associated with plastic change in the adult rat barrel receptor complex. Brain Res Mol Brain Res. 1993;18(1-2): 59-70.

87. Lin LH, Bock S, Carpenter K, Rose M, Norden JJ. Synthesis and transport of GAP-43 in entorhinal cortex neurons and perforant pathway during lesion-induced sprouting and reactive synaptogenesis. Brain Res Mol Brain Res. 1992;14(1-2):147-153.

88. Cantallops I, Routtenberg A. Rapid induction by kainic acid of both axonal growth and F1/GAP-43 protein in the adult rat hippocampal granule cells. J Comp Neurol. 1996;366(2):303-319.

89. Akers RF, Routtenberg A. Protein kinase C phosphorylates a $47 \mathrm{Mr}$ protein (F1) directly related to synaptic plasticity. Brain Res. 1985;334(1): $147-151$.

90. Routtenberg A, Lovinger DM. Selective increase in phosphorylation of a 47-kDa protein (F1) directly related to long-term potentiation. Behav Neural Biol. 1985;43(1):3-11.

91. Son H, Davis PJ, Carpenter DO. Time course and involvement of protein kinase C-mediated phosphorylation of F1/GAP-43 in area CA3 after mossy fiber stimulation. Cell Mol Neurobiol. 1997;17(2):171-194. 
92. Lovinger DM, Akers RF, Nelson RB, Barnes CA, McNaughton BL, Routtenberg A. A selective increase in phosporylation of protein F1, a protein kinase $\mathrm{C}$ substrate, directly related to three day growth of long term synaptic enhancement. Brain Res. 1985;343(1):137-143.

93. Namgung U, Matsuyama S, Routtenberg A. Long-term potentiation activates the GAP-43 promoter: selective participation of hippocampal mossy cells. Proc Natl Acad Sci U S A. 1997;94(21):11675-11680.

94. Ramakers GM, De Graan PN, Urban IJ, et al. Temporal differences in the phosphorylation state of pre- and postsynaptic protein kinase C substrates B-50/GAP-43 and neurogranin during long-term potentiation. J Biol Chem. 1995;270(23):13892-13898.

95. Ramakers GM, McNamara RK, Lenox RH, De Graan PN. Differential changes in the phosphorylation of the protein kinase $\mathrm{C}$ substrates myristoylated alanine-rich $\mathrm{C}$ kinase substrate and growth-associated protein-43/B-50 following Schaffer collateral long-term potentiation and long-term depression. J Neurochem. 1999;73(5):2175-2183.

96. Meberg PJ, Valcourt EG, Routtenberg A. Protein F1/GAP-43 and PKC gene expression patterns in hippocampus are altered $1-2 \mathrm{~h}$ after LTP. Brain Res Mol Brain Res. 1995;34(2):343-346.

97. Meberg PJ, Barnes CA, McNaughton BL, Routtenberg A. Protein kinase $\mathrm{C}$ and F1/GAP-43 gene expression in hippocampus inversely related to synaptic enhancement lasting 3 days. Proc Natl Acad Sci US A. 1993;90(24):12050-12054.

98. Fedorov NB, Pasinelli P, Oestreicher AB, DeGraan PN, Reymann KG. Antibodies to postsynaptic PKC substrate neurogranin prevent longterm potentiation in hippocampal CA1 neurons. Eur J Neurosci. 1995;7(4):819-822.

99. Hulo S, Alberi S, Laux T, Muller D, Caroni P. A point mutant of GAP-43 induces enhanced short-term and long-term hippocampal plasticity. Eur J Neurosci. 2002;15(12):1976-1982.

100. Luo Y, Vallano ML. Arachidonic acid, but not sodium nitroprusside, stimulates presynaptic protein kinase $\mathrm{C}$ and phosphorylation of GAP-43 in rat hippocampal slices and synaptosomes. J Neurochem. 1995;64(4):1808-1818.

101. Rekart JL, Meiri K, Routtenberg A. Hippocampal-dependent memory is impaired in heterozygous GAP-43 knockout mice. Hippocampus. $2005 ; 15(1): 1-7$.
102. Young E, Cesena T, Meiri KF, Perrone-Bizzozero NI. Changes in protein kinase $\mathrm{C}$ (PKC) activity, isozyme translocation, and GAP-43 phosphorylation in the rat hippocampal formation after a single-trial contextual fear conditioning paradigm. Hippocampus. 2002;12(4): 457-464.

103. Aigner L, Arber S, Kapfhammer JP, et al. Overexpression of the neural growth-associated protein GAP-43 induces nerve sprouting in the adult nervous system of transgenic mice. Cell. 1995;83(2):269-278.

104. Holahan M, Routtenberg A. The protein kinase C phosphorylation site on GAP-43 differentially regulates information storage. Hippocampus. 2008;18(11):1099-1102.

105. Holahan MR, Honegger KS, Tabatadze N, Routtenberg A. GAP-43 gene expression regulates information storage. Learn Mem. 2007; 14(6):407-415.

106. Maviel T, Durkin TP, Menzaghi F, Bontempi B. Sites of neocortical reorganization critical for remote spatial memory. Science. 2004; 305(5680):96-99.

107. Lerch JP, Yiu AP, Martinez-Canabal A, et al. Maze training in mice induces MRI-detectable brain shape changes specific to the type of learning. Neuroimage. 2011;54(3):2086-2095.

108. Narayana PA, Herrera JJ, Bockhorst KH, et al. Chronic cocaine administration causes extensive white matter damage in brain: diffusion tensor imaging and immunohistochemistry studies. Psychiatry Res. 2014;221(3):220-230.

109. Gnegy ME, Hong P, Ferrell ST. Phosphorylation of neuromodulin in rat striatum after acute and repeated, intermittent amphetamine. Brain Res Mol Brain Res. 1993;20(4):289-298.

110. Park YH, Kantor L, Wang KK, Gnegy ME. Repeated, intermittent treatment with amphetamine induces neurite outgrowth in rat pheochromocytoma cells (PC12 cells). Brain Res. 2002;951(1):43-52.

111. Grignaschi G, Burbassi S, Zennaro E, Bendotti C, Cervo L. A single high dose of cocaine induces behavioural sensitization and modifies mRNA encoding GluR1 and GAP-43 in rats. Eur J Neurosci. 2004; 20(10):2833-2837.

112. Kim HJ, Choi KM, Ku BM, et al. Acute ethanol administration decreases GAP-43 and phosphorylated-GAP-43 in the rat hippocampus. Brain Res. 2006;1112(1):16-25.
Research and Reports in Biochemistry

\section{Publish your work in this journal}

Research and Reports in Biochemistry is an international, peer-reviewed, open access journal publishing original research, reports, reviews and commentaries on all areas of biochemistry. The manuscript management system is completely online and includes a very quick and fair
Dovepress

peer-review system. Visit http://www.dovepress.com/testimonials.php to read real quotes from published authors. 